\title{
Fragmente de viaţă parohială \\ din zona Năsăudului \\ între anii 1950-1961
}

Călin Emilian CIRA*

\begin{abstract}
In the 20th century, the Romanian Orthodox Church went through times of hardship, especially during the communist period, marked by a materialistic and atheistic perspective on the world. Many priests were arrested, and ecclesiastical activity was reduced to the liturgical dimension. In this context, the Church sought ways to continue its mission of preaching the Word of God, despite the restrictive conditions. In this text, we present some actions through which the communist regime affected parish life in the Năsăud area during the years 1950-1960.
\end{abstract}

Keywords: Romanian Orthodox Church, communism, parish life.

\section{Introducere}

În veacul al XX-lea, Biserica Ortodoxă Română a trecut prin vremuri de restrişte, mai ales în timpul perioadei comuniste, marcate printr-o perspectivă materialistă şi ateistă despre lume. Omul a fost redus strict la dimensiunea sa economică, iar întreaga istorie la lupta dintre clasele sociale: „[...]Este deci la mijloc o înțelegere materialistă a istoriei și a lucrurilor, de unde și numele de materialism istoric. Concepția aceasta aplică adică istoriei ideea unei desvoltări conduse de legi determinate și atârnând de desvoltarea raporturilor economice"1. Comunismul militează pentru desfiinţarea proprietăţii

* Bibliotecar cercetător la Biblioteca Centrală Universitară „Lucian Blaga” ClujNapoca; cadru didactic asociat la Universitatea „Babeș-Bolyai” dn Cluj-Napoca.

1 Petre F. Alexandru, Biserica și comunismul, Huși, Edit. Tipografia George Cerchez,1937, p. 11. 
private, a familiei, a religiei. Cea din urmă este considerată „opiu pentru popor" deoarece împiedică clasele exploatate să se revolte şi să-şi obţină libertatea: ,[...] Principiile sociale ale creștinismului predică lașitatea, disprețul de sine, înjosirea, supunerea, umilința, pe scurt toate însușirile drojdiei societății, iar proletariatul, care nu acceptă să se lase tratat ca drojdie a societății, are mai multă nevoie de curajul, de demnitatea, de mândria sa şi de spiritul său de independență decât de pâinea sa. Principiile sociale ale creștinismului sunt fățarnice, iar proletariatul este revoluționar. Iată cum stau lucrurile cu principiile sociale ale creștinismului"'2. Lenin întăreşte această afirmaţie: ,Religia este opiu pentru popor - această maximă a lui Marx este piatra unghiulară a întregii concepții marxiste în problema religiei. Marxismul consideră întotdeauna toate religiile și bisericile contemporane, toate organizațiile religioase ca pe niște organe ale reacțiunii burgheze, care slujesc la apărarea exploatării și la narcotizarea clasei muncitoare"3. Din acest motiv, partidul are obligaţia de a lupta împotriva obscurantismului religios: „Întregul nostru program este bazat pe o concepție științifică despre lume, și anume pe concepția materialistă. De aceea, explicarea programului nostru include în mod necesar și explicarea adevăratelor rădăcini istorice şi economice ale obscurantismului religios. Propaganda noastră include în mod necesar și propagarea ateismului; editarea literaturii științifice corespunzătoare, care până acum a fost strict interzisă și urmărită de puterea de stat absolutist-iobăgistă, trebuie să constituie acum unul din sectoarele muncii noastre de partid. Va trebui, probabil, să urmăm sfatul pe care 1-a dat cândva Engels socialiștilor germani: de a traduce și a difuza în mase literatura franceză iluministă și ateistă din secolul al XVIII-lea"4. Aceste idei au avut urmări tragice în viaţa multor oameni ai credinţei care au cunoscut, în ţările aflate sub stăpânirea unui astfel de regim criminal, prigoana.

2 Karl MarX, Friedrich Engels, Despre religie, ediția a II-a, București, Edit. Politică, 1960, p. 76-77.

3 Vladimir I. LENIN, Despre religie, București, Edit. de Stat pentru Literatură Politică, 1956, p. 18-19.

${ }^{4}$ Ibidem, p. 10. 
După cel de-al Doilea Război Mondial, şi în România s-au aplicat toate aceste idei, în urma intrării ei în sfera de influenţă sovietică. Confesiunile creştine au fost supuse unui control strict din partea statului. Mulţi preoţi, monahi şi credincioşi au fost arestaţi pentru faptul că au fost mărturisitori ai lui Hristos. Lupta împotriva credinţei $\mathrm{s}-\mathrm{a}$ concretizat și prin desfiinţarea multor mănăstiri și închiderea şcolilor confesionale. $\mathrm{O}$ altă metodă prin care s-a încercat atragerea tineretului la ,noul regim” a fost eliminarea predării disciplinei „Religie” din şcolile publice şi înlocuirea ei cu transmiterea învățăturilor ateiste. În acest context potrivnic, Biserica Ortodoxă a căutat diverse metode prin care să-şi împlinească misiunea de slujire și propovăduire a Evangheliei.

În următoarele rânduri, vom exemplifica cum a fost realizată această lucrare în câteva parohii din zona Năsăudului. Este vorba de un studiu de caz prin care se ilustrează activitatea parohială întro epocă ostilă credinţei, arătând cum a fost afectată viaţa liturgică și pastoral-misionară de către acest regim. Am folosit în acest scop „circularele” emise de Episcopia Ortodoxă Română a Vadului, Feleacului şi Clujului, precum şi ,raportul de activitate” întocmit şi redactat de fiecare preot paroh şi de conducerea protopopiatului năsăudean. Menţionăm faptul că din punct de vedere cronologic ne concetrăm asupra anilor '50-'60 ai veacului trecut.

\section{Parohia - centru al vieţii pastoral-misionare}

Parohia ocupă în viaţa eclezială un rol fundamental, deoarece viaţa de credinţă a credincioşilor se desfăşoară în cadrul acesteia. În Statutul pentru Organizarea şi Funcţionarea Bisericii Ortodoxe Române, adoptat în anul 1949, parohia era definită astfel: „,comunitatea bisericească a credincioşilor, clerici şi mireni, de religie creştin ortodoxă aşezaţi pe un anumit teritoriu, sub conducerea unui preot paroh"5. Acelaşi statut prevedea foarte clar obligațiile pe care le

5 *** Statutul pentru Organizarea şi Funcţionarea Bisericii Ortodoxe Române, București, Edit. Institutului Biblic şi de Misiune Ortodoxă, 1949, p.13. 
au clericii şi mirenii. Rolul laicatului este astfel definit: „Membrii parohiei au îndatorirea: a susţine, întări şi răspândi credinţa Bisericii Ortodoxe; a lucra astfel ca toţi credincioşii să vieţuiască potrivit învăţăturilor acestei credinţe; a cerceta sfânta biserică, a participa la sfintele slujbe; a se împărtăşi cu sfintele taine; a îndeplini faptele milei creştine; a întreţine şi ajuta Biserica şi pe slujitorii ei"6. Acesta a fost un aspect foarte important mai ales în acel context dificil în care s-a încercat reducerea rolului Bisericii în viaţa oamenilor.

Biserica, în ciuda vicisitudinilor, nu a capitulat, ci şi-a continuat misiunea mântuitoare. Pentru aceasta, preoţii au folosit atât mijloacele pastoraţiei colective, ,adică acelea prin care urmărim şi realizăm pastoraţia sau conducerea sufletească a tuturor enoriaşilor din parohie, sau a marii lor majorităţi, indiferent de vârstă, sex, nivelul moral sau intelectual ori profesiunea şi îndeletnicirile lor ş.a.m.d.; cele mai des folosite dintre acestea sunt: cultul divin (slujbele săvârşite în biserici), predica şi cateheza, la care se adaugă cuvântul tipărit, sub diferitele lui forme (carte sau volum, revistă, ziar, album, foaie volantă etc.)"'7, precum şi metodele pastoraţiei individuale prin contactul $\mathrm{cu}$ credinciosul realizat prin intermediul vizitelor pastorale, savârşirea anumitor ierurgii şi mai ales prin Taina Spovedaniei ${ }^{8}$.

Şi în parohiile din părțile Năsăudului clerul a aplicat aceste metode pastorale, fapt pe care îl vom ilustra în cele care urmează.

\section{Viaţa liturgic şi transmiterea învățăturilor de credinţă}

Regimul comunist a încercat reducerea activităţii Bisericii strict la dimensiunea liturgică, fundamentală în cadrul Bisericii Ortodoxe. Sfânta Liturghie, Sfintele Taine şi ierurgiile sunt mijloacele prin care harul divin este împărtăşit credincioşilor.

\footnotetext{
${ }^{6}$ Ibidem.

${ }^{7}$ Ene BRANişTE, ,Mijloace şi metode de lucru în activitatea pastorală şi misionară a preoţimii de azi”, în Biserica Ortodoxă Română. Buletinul Oficial al Patriarhiei Române, Anul XCIX, Nr.1-2, ianuarie-februarie 1981, p. 47.

${ }^{8}$ Ibidem.
} 
Totodată ele au şi un conţinut învăţătoresc deoarece slujbele bisericeşti cuprind norma de credinţă ortodoxă. Dacă regimul a redus posibilitatea clerului de a-şi împlini vocaţia în mod deplin prin diverse mijloace, Biserica a găsit să răspundă printr-o preocupare asiduă pentru buna desfăşurare a vieţii liturgice.

Astfel, de exemplu, în anul 1955 Eparhia Vadului, Feleacului şi Clujului sub jurisdicţia căreia se afla zona Năsăudului, episcopul, printr-o circulară, își manifestă purtarea de grijă ca toţi credincioşii să poată beneficia de posibilitatea de a participa la cultul divin şi de a se spovedi şi împărtăşi cu ocazia sărbătorilor pascale: „Cu ajutorul Domnului ne apropiem de Sfintele Sărbători ale Învierii.

Ne place să credem că în tot timpul postului - ca de altfel în toată bunăvremea - preoţimea noastră s-a nizuit să verse belşug de mîngăiere duhovnicească, în inimile credincioşilor încredinţaţi spre păstorire.

Dar cum «secerişul este bogat, iar secerătorii mai puţini» ne gîndim la parohiile vacante şi chiar la unele filii cari le au parohiile noastre, cari aşteaptă cu aceeaşi legitimă dorinţă să se bucure şi ele de Marele Praznic. Asta ne face să îndemnăm pe slujitorii Altarului să-şi îndoiască strădaniile ca nici un credincios - din cei care doresc - să nu rămînă nemărturisit şi neîmpărtăşit de Sf. Paşti.

Acolo unde nevoia o cere, e bine ca însuşi P.C. Voastră să întocmiţi programul după care preoţii care administrează parohii vacante, ca şi cei cu mai multe filii, să slujească spre a satisface după putinţă - pe toţi.

În special, se vor respecta îndrumările noastre date şi cu alte ocaziuni, că la o biserică se săvârşeşte Sf. Liturghie, iar la alta în aceeaşi zi Vecernia. Slujba Sf. Învieri deasemenea se poate face în două biserici: la ora 12 într-una /fără Sf. Liturghie/ şi dimineaţa într-altă biserică, cu Sf. Liturghie.

Aducîndu-vă acestea la cunoştinţă, ne rugăm Bunului Dumnezeu să păzească sănătatea preoţimii noastre ca şi a P.C. Voastre, spre o cît mai fructuoasă lucrare în Via Domnului"”.

9 Arhiva Protopopiatului Ortodox Român Năsăud, Dosar Corespondenţă 1955, Onor Oficiul Protopopesc Năsăud, Prea Cucernice Părinte Protopop, filă nenumerotată. 
Deseori se impunea preoților ca, în Duminici şi sărbători, Sfânta Liturghie să fie savârşită cât mai de dimineață pentru ca apoi toți credincioșii „să iasă la muncile câmpului” și la „alte activităţi”. Astfel, parohul din localitatea Dumitra, Iuliu Crişan, scria că a terminat, într-o zi de Duminică, mai devreme Sfânta Liturghie pentru ca sătenii să poată participa la o şedinţă: ,, In dimineaţa zilei de 5 Nov. a.c. (duminica) în înţelegere cu conducerea G.A.C. din Cepari, am terminat liturghia la orele 10 , pt. a putea lua parte credincioşii la şedinţa G.A.C. [...]"10, iar preotul din Nepos menționa în raportul de activitate: „Subsemnatul preot vin a raporta că în munca de folos obştesc de la 15 August până la 5 Septembrie anul curent am săvârşit următoarele, mi-am treierat ultimii snopi ce i-am avut la întovărăşire, dând grâul cuvenit la contract. În ziua de 29 August (Tăierea Capului Sf. Ioan Botezătorul) am ieşit la ora 10 din biserică fiind treierişul întărziat şi am sfătuit poporul să meargă la treierat [...]"11. Astfel, cultul divin a devenit ceva secundar faţă de „munca pe ogoare”. Preoții și credincioșii au înțeles „mesajul” și bisericile nu s-au golit, ci dimpotrivă, mai mulți credincioşi au participat la sfintele slujbe rugându-se cu râvnă și dragoste pentru Hristos.

Pe lângă săvârşirea Sfintelor Taine o preocupare deosebită în epocă a fost transmiterea învăţăturii de credinţă. Aceasta se făcea prin intermediul omiliilor şi catehezelor. În fiecare Duminică şi sărbătoare, în cadrul Sfintei Liturghii se predica. Cu prilejul înmormântărilor, dar şi al altor ierurgii, preotul rostea un cuvânt de învăţătură.

Cateheza era un alt mijloc prin care era transmisă şi întărită credinţa copiiilor și adulților. La nivelul Patriarhiei încă de la începutul anilor '50 exista această preocupare: ,Vă trimitem programa cu subiectele catehezelor fixate de Sfânta Patriarhie. În proxima conferință lunară, P.C. Voastră o veți dicta preoților, iar aceștia își vor lua însemnări, din punct în punct.

10 Arhiva Protopopiatului Ortodox Năsăud, Dosar Corespondenţă 1961, Parohia ort. rom. Dumitra, R. Năsăud, Nr.161/1961, filă nenumerotată.

11 Arhiva Protopopiatului Ortodox Năsăud, Dosar Corespondenţă 1961, Oficiul parohial ort. rom. Nepos, Nr.121/1961, filă nenumerotată. 
În catehizație se vor călăuzi după această programă și, în măsura posibilităților, vor căuta să satisfacă aceste îndatoriri [...]"12. În anul 1952 cu ocazia unei conferinţe a protopopilor desfăşurată la 10 ianuarie, referitor la catehizare se menționau următoarele: , ,[...] 1/Atragem preoțimii noastre luarea aminte asupra îndatoririi de a catehiza. Fiecare dintre CC. preoți va face raport oficialului protopopesc în termen de cel mult cinci zile de la data prezentei circulare, menționând ziua și ora când face catehizarea. P.C. Protopopi vor întocmi un tablou cuprinzând parohiile și filiile din raion, și îl vor înainta Consiliului Eparhial cel mai târziu în proxima zi după conferința preoțească din Ianuarie a.c. [...]"13. Catehizarea se făcea deseori Duminica după Vecernie, fapt consemnat în raportul de activitate de fiecare preot. Astfel, preotul paroh din Maieru scria: „Cu onoare raportez că pentru pruncii școlari se face cateheza regulată în fiecare Duminică la ora 2,1/2 d.a. după vecernie. Frecventează circa 100 copii. Cei cari locuiesc la depărtare mai mare vin neregulat. În lunile de primăvară frecvența e mai bună. Celor adulți li se ține predici catehetice de serie, în fiecare Duminică, regulat li se explică Catehismul cel mare. În anul 1955 am început explicarea Catehismului p. I (Credința), în a.c. am tratat partea a II-a (Poruncile) urmând ca în viitor 1957 să tratez p. III (Sf. Taine)"14.

În anul 1958 Preasfinţitul Teofil Herineanu, episcopul Vadului, Feleacului şi Clujului solicită întocmirea unei noi programe de cateheză. Încredințează realizarea acesteia părintelui profesor Liviu Galaction Munteanu care, la rândul lui, îl cheamă în ajutor pe părintele Ioan Bunea pentru a-1 sprijini în acest efort. La 26 august 1958 Episcopia Ortodoxă din Cluj trimite către protopopiatele din subordine adresa cu numărul 5932/1958 prin care îndeamnă protopopii ca „la conferința administrativă din luna octombrie să dezbată cu preoții mai multe probleme” și să fie luate „hotărîri în sensul concluziilor de la

12 Arhiva Protopopiatului Ortodox Român Năsăud, Dosar Corespondenţă 1951, Episcopia Ortodoxă Română Cluj, Nr.4901/1951, fila 151.

13 Arhiva Protopopiatului Ortodox Român Năsăud, Dosar Corespondenţă 1952, Episcopia Ortodoxă Română Cluj, Nr.117/1952, filă nenumerotată.

14 Arhiva Protopopiatului Ortodox Român Năsăud, Dosar Corespondență 1956, Oficiul parohial ort. român Maieru, Nr.251/1956, filă nenumerotată. 
Conferința cu Protoiereii ținută în Centrul Eparhial la 20 august"15. La capitolul II pct. 10 se scrie: „Catehizarea copiilor:

a. conscrierea și gruparea

b. ciclul I: cl. I-II

c. ciclul II: cl. III-IV

d. ciclul III: cl. V-VII

Povestioare morale religioase, rugăciuni, Sf. Scriptură, Catehism. Până la 15 septembrie a.c. va fi trimis de la Centrul Eparhial programa analitică și toate îndrumările necesare asupra materialului didactic [...]. La pct. 11: Catehizarea adulţilor. La acatistele de miercuri seara și vecerniile de Duminică 20 minute «Cuvânt de învățătură». Se va trimite programa analitică cu schița temelor pentru întregul an bisericesc, sept. 1958 - sept. 1959"'16. Regimul politic a reacţionat foarte dur în raport cu această programă deoarece a considerat că este o formă de subminare a orânduirii de stat, atee: ,„[...] Ce se făcuse însă nu era în vederile factorului politic, de aceea programa a fost retrasă, fiind considerată împotriva învăţământului de stat, acum ateu"17. Imediat cei doi preoţi au fost arestaţi, părintele Liviu Galaction Munteanu murind în închisoarea din Aiud în anul $1961^{18}$. Prin arestarea celor doi preoți s-a reuşit demotivarea clerului de a mai face catehizare, iar de la nivelul episcopiei nu au mai fost astfel de iniţiative, decât sporadic și tainic.

\section{Implicarea preoților în viața comunitară}

România la începutul anilor '50 era o țară cu o populaţie majoritar rurală. În acest mediu, preotul reprezenta un model de

15 Arhiva Protopopiatului Ortodox Român Năsăud, Dosar Corespondență 1958, Episcopia Ortodoxă Română Cluj, Nr.5932/1958, filă nenumerotată.

16 Ibidem.

${ }^{17}$ Ioan BunEA, Memorial, Cluj-Napoca, Edit. Limes, 2015, p. 129.

18 Pentru o prezentare mai în detaliu, vezi Călin Emilian CIRA, „Fragmente din istoria catehezei în Episcopia Clujului între anii 1950-1958", în Arhiva Someşană. Revistă de istorie şi cultură, Seria a III-a, XIV, Năsăud, 2015, p. 297-310. 
urmat pentru credincioşi. El avea şi un rol educativ nu doar pe planul spiritual-moral, ci şi în probleme de ordin administrativ. De multe ori, datorită încrederii de care se bucura în rândul parohienilor pentru îndrumările duhovnicești, preotul era nevoit să ofere și învățături „agronomice" și să încurajeze plata diverselor dări și cote către stat. Acesta era și un mod prin care preoțimea își arăta implicarea și utilitatea în viața statului. Astfel, în predici sau cu alte ocazii, preoții vorbeau despre combaterea dăunătorilor și pomicultură, după cum reiese și din documentul emis de Parohia Ortodoxă Nimigea de Sus în anul 1954, din care reproducem un fragment:

,În ziua de 10 ianuarie 1954.

O conferință despre rolul insectelor în gospodăria plugarului. Insecte folositoare ca albinele și altele păgubitoare. Cine vine în ajutorul agriculturii să le restrîngă. Paserile: paserile folositoare care se hrănesc cu insecte. Ocrotirea acestora și amenajarea lor cu cuiburi artificiale și ceva hrană în timpul iernei etc.

În 7 februarie 1954. Despre pomicultură. Însemnătatea acesteia. Curăţirea uscăturii și aranjarea coroanei pomilor. Instrumentele necesare. Curățirea tulpinelor și a crengilor mai groase. Îngrijirea scoarței și curățarea ei cu peria de sîrmă [...]"19.

Și la nivel superior se solicita implicarea intensă a clerului în aceste activități: ,Secerișul holdelor este în toi. Grija de căpetenie a fiecărui muncitor conștient este ca lucrările împreunate cu adunarea recoltei de pe cîmp, trasportarea la arie, treerișul, predarea cotelor și transportarea lor la baza de recepție să fie săvîrșită la timp și în cele mai bune condițiuni.

De aceea atragem preoțimii noastre luarea aminte să îndemne credincioșii din parohii, asupra îndeplinirii cu conștiinciozitate a lucrărilor și îndatoririlor cetățenești mai sus menționate.

În toiul muncilor sezoniere, serviciul divin în biserică se poate săvârşi mai devreme ca de obicei, pentru ca oamenii să poată ajunge și la lucrul câmpului, când aceasta o va reclama urgența

19 Arhiva Protopopiatului Ortodox Român Năsăud, Dosar Corespondență 1954, Nimigea de Sus. N: 18-1954, Tablou dspre activitatea preotului afară de biserică în 1954, f.1. 
timpului favorabil și executarea în cele mai bune condiţiuni a oricărei lucrări din lupta pentru bunăstarea poporului, pentru întărirea Patriei și pentru apărarea păcii.

Despre mersul lucrărilor în parohii, cucernicii preoți vor face raport oficiilor protopopești din două în două săptămâni, iar P.C. Protopopi ne vor raporta nouă"

Preoții nu doar că aveau obligația să vorbească despre aceste teme, ci trebuiau să şi le însușească pentru a fi model sătenilor. Astfel, unii, s-au înscris în întovărăşirile agricole: „Preotul Teodor Oprea din Floreşti luând parte la adunările obşteşti în legătură cu socializarea agriculturii şi-a dat tot aportul în legătură cu lămurirea credincioşilor raportând: «Eu ca preot m-am înscris cu întreagă suprafaţa agricolă în întovărăşirea Drumul Belşugului, asemenea Ilisiu Sever epitrop, Ciui Silvestru cantor, Moldovan Ioan făt, Moldovan Nicolaie, Rusu Grigore, Demian Ioan, Ilisiu Valentin, Ilisiu Simion, Rusu Vasile, Muresan Leonte, toţi consilieri ai bisericii până în prezent sunt înscrişi 80 de familii din cele 120 .

Asemenea ne raportează şi preotul Zagrai Petru din Mititei că duce muncă de lămurire în acea problemă.

3/ Urmare circularei oficiului protopopesc Năsăud dată preoţilor în legătură cu contractările pe 1959 preoţii ne raportează că înşişi au contractat.

Pop Iuliu de la Maieru $100 \mathrm{~kg}$ porumb, Teodor Oprea Florești $90 \mathrm{~kg}$ grâu şi porumb, Zagrai Petru Mititei $200 \mathrm{~kg}$ cereale, preotul Ciocirla Emil a lămurit pe credinciosul Ioan Calini care a contractat $500 \mathrm{~kg}$ orzoaică şi pe Ioan Cacior care a contractat 5001 lapte"21.

Relaţia preotului cu autoritatea locală este oglindită în documentele acelor timpuri, unde descoperim pe slujitorul altarului care „s-a făcut tuturor toate” pentru ca viața parohiei să nu fie tulburată. Nu erau puține cazurile când preoții erau solicitați pentru a contribui la rezolvarea diverselor probleme care priveau

20 Arhiva Protopopiatului Ortodox Român Năsăud, Dosar Corespondență 1956, Episcopia Ortodoxă Română Cluj, Nr.3962/1956, filă nenumerotată.

${ }^{21}$ Arhiva Protopopiatului Ortodox Român Năsăud, Dosar Corespondenţă 1959, Of. Protopopesc Ort. Rom. raion Năsăud, Către Împuternicitul Regional al Cultelor, filă nenumerotată. 
comunitatea: „Contactul cu sfaturile populare se ține peste tot în măsura în care organele de conducere locală apelează la sprijinul preotului în diferite probleme locale" ${ }^{22}$. Pe lângă acele chestiuni din sfera activităților agricole și a plății cotelor, clerul era implicat și în lucrări utile precum electrificarea localităților: „Am ţinut legătura cu organele Sfatului popular şi în acest scop am participat şi la şedinţele unde preoţii au fost convocaţi, anume: privind electrificarea comunei, unde pr. Henciu a făcut lucrări de verificare a operaţiunilor împreună cu comisiunea de revizie, iar pr. Bondane a fost pe teren cu comisiunea cetăţenească, pentru lucrările de finisare a traseului aerian [... $]^{\prime 23}$.

Dar nu întotdeauna aceste relaţii au fost bune. În unele sate au apărut conflicte între reprezentanți ai statului și clerici: „Subsemnatul Preot Pavel Climescu din satul Gersa 2, fără ură şi fără părtinire raportez următoarele: dl Preşedinte interpretează legea cultelor greşit. Spune că a face slujbe particulare în cursul săptămânii la intenţia credincioşilor înseamnă propagandă ostilă statului şi misticism. Mi-a interzis a mai oficia liturghii în cursul săptămînii, particulare, cu ameninţarea că-mi va arăta el mie... Mă va da în judecată... Nici pentru mine personal, de e seară, n-am voie a mă ruga în biserică, ci în casa parohială. $\mathrm{Nu}$ e cult al personalităţii când ne face să tremurăm de umbra lui? Dictatură personală şi nu proletară, câtă vreme jigneşte sentimentul religios sau alte sentimente vrednice. Când îl apucă nervii suduie de mamă şi cum îi vine la gură...Nu e rău la inimă, e drept, dar femeile îs îngrozite când dau cu ochii de el şi bărbaţii aşişderea... Fug care încotro... Îmi interzice a mai face pace între cei învrăjbiţi... Cu trei zile în urmă am împăcat pe soţ şi soţie (familia Helgiug) ca să nu se despartă. Ajunsese la violenţă... Saveta Helciug, venise la nevastămea să arate cum e de vânătă. Nevastă-mea, plângând mi-a spus, să fac pace între ei. [...] Apoi i-am chemat pe amândoi în biserică... Şi

${ }^{22}$ Arhiva Protopopiatului Ortodox Român Năsăud, Dosar Corespondență 1956, Of. Protopopesc Ort. Rom, Nr.484, Anul 1956, Luna VIII, ziua 7, filă nenumerotată.

${ }^{23}$ Arhiva Protopopiatului Ortodox Român Năsăud, Dosar Corespondenţă 1957, Oficiul parohiei ort. rom. TELCIU, Nr.7-1957, filă nenumerotată. 
s-au împăcat... Pentru că prin acest fapt au renunţat a merge a se pârî la Sfat şi la Miliţie şi la Tribunal pentru divorţ îs acuzat că îmi asum atribuţii ce [cuvânt neclar]: «Să-i fi lăsat să divorţeze [...]» a fost replica nervoasă a dlui Preşedinte. Altă dată o să te dăm în judecată a zis tot el [...]. Îs acuzat cum că opresc oamenii să reclame furturi... Dimpotrivă când vin oamenii la rugăciune pentru descoperirea furtului, îi îndemn a reclama la miliţie... [...]"24.

Misiunea Bisericii, în această perioadă, a fost restrânsă foarte mult și prin faptul că mulți preoți au cunoscut închisorile regimului comunist. Ei au fost închişi pentru misiunea pe care o desfăşurau și care a fost considerată a fi împotriva ,orânduirii de partid și de stat”. Eparhia Vadului, Feleacului și Clujului a avut o grijă și o preocupare aparte față de acești clerici: „S-a întâmplat că unii preoți au fost arestați și judecați sau au fost deținuți un timp oarecare pentru cercetări, iar PP. CC-lor părinții protopopi nu ne-au raportat decât după ce au trecut luni de zile sau după ce ne-am sesizat noi și le-am cerut lămuriri.

Pentru a nu se mai repeta situaţia aceasta vă rugăm ca ori de câte ori se întâmplă arestarea sau deținerea vreunui preot să ne raportați în termen de trei zile despre aceasta, iar cu privire la salarizarea acestora să vă conformați dispozițiilor date în acest sens, precum şi dispoziţiilor cuprinse în circulara noastră recentă privind întocmirea statelor de plată. Dacă vreunul din cei arestați sau deținuți a fost judecat fie că a fost condamnat, fie că a fost achitat - îndată după ce cunoașteți hotărârea dată să ne raportați despre aceasta"25.

Colectivizarea a fost un alt factor care a slăbit din punct de vedere economic parohiile: ,Binevoiți a ne da dispoziții a mai ține această ecleje Preoțească, sau să o predăm Sfatului Popular, cu Proces Verbal; bine ar fi dacă s-ar putea să rămână, iar dacă nu, o vom preda" 26 . Din această afirmație reiese situaţia financiară grea pe care unele parohii o aveau în urma pierderii terenurilor agricole.

${ }^{24}$ Arhiva Protopopiatului Ortodox Român Năsăud, Dosar Corespondență 1961, Parohia Bis. Gersa 2, Nr.77, 23.XI.1961, filă nenumerotată.

25 Arhiva Protopopiatului Ortodox Român Năsăud, Dosar Corespondență 1958, Episcopia Ortodoxă Română Cluj, Nr. 4723/1958, filă nenumerotată.

${ }^{26}$ Arhiva Protopopiatului Ortodox Român Năsăud, Dosar Corespondență 1958, Of. Parohial ort. rom. Poienile Zăgrii Suplai, Nr. 43/958, filă nenumerotată. 


\section{În loc de concluzii}

Perioada regimului comunist a fost pentru Biserică una dificilă. Sigur, s-au făcut și unele compromisuri precum susținerea unor politici ale statului (colectivizarea agriculturii, plata cotelor...). Dar, cu toate acestea, preoțimea a fost la înălțimea slujirii, cu orice riscuri. Unii preoți au fost arestați, iar multor parohii li s-au confiscat proprietăţile, fapt ce le-a diminuat puterea economică. Programul liturgic era deseori tulburat de obligativitatea creștinilor de a fi prezenți la lucrările agricole. $\mathrm{Cu}$ toate acestea, Biserica a fost $\mathrm{o}$ prezență importantă în comunitate. Credincioșii nu au fost lipsiți de Sfintele Taine și ierurgii. S-a insistat pe transmiterea învățăturii ortodoxe prin intermediul predicii și catehezelor. Față de cele din urmă a existat un interes special din partea Eparhiei Vadului, Feleacului și Clujului în contextul în care disciplina „Religie” nu mai era predată în școli, iar ateismul era politică de stat. Prin intermediul catehezelor s-a încercat o contrapondere la învățământul ateu, fapt ce a dus până la urmă la dispariţia acestei forme de învățământ religios după anul 1958. În ciuda acelor vremuri grele preoții din zona Năsăudului au reușit să-şi împlinească misiunea de propovăduire a Cuvântului lui Dumnezeu și să păstreze vie credința în inima celor pentru care Hristos este „Calea, Adevărul și Viața”.

$\cos 80$

\section{Bibliografie}

1. *** Statutul pentru Organizarea şi Funcţionarea Bisericii Ortodoxe Române, București, Edit. Institutului Biblic şi de Misiune Ortodoxă, 1949.

2. AleXANDRU, Petre F., Biserica și comunismul, Huși, Edit. Tipografia George Cerchez, 1937.

3. BRANIŞTE, Ene, „Mijloace şi metode de lucru în activitatea pastorală şi misionară a preoţimii de azi”, în Biserica Ortodoxă Română. Buletinul Oficial al Patriarhiei Române, Anul XCIX, Nr.1-2, ianuarie-februarie 1981, p.47-58. 
4. BunEA, Ioan, Memorial, Cluj-Napoca, Edit. Limes, 2015.

5. LENIN, Vladimir I., Despre religie, București, Edit. de Stat pentru Literatură Politică, 1956.

6. MARX, Karl / ENGELS, Friedrich, Despre religie, ediția a II-a, București, Edit. Politică, 1960.

\section{Documente de arhiva Protopopiatului Ortodox Român Năsăud:}

1. Dosar Corespondenţă 1951, Episcopia Ortodoxă Română Cluj, Nr. 4901/1951.

2. Dosar Corespondenţă 1952, Episcopia Ortodoxă Română Cluj, Nr.117/1952.

3. Dosar Corespondență 1954, Nimigea de Sus. N: 18-1954, Tablou despre activitatea preotului afară de biserică în 1954.

4. Dosar Corespondenţă 1955, Onor Oficiul Protopopesc Năsăud, Prea Cucernice Părinte Protopop.

5. Dosar Corespondență 1956, Oficiul parohial ort. român Maieru, Nr. 251/1956.

6. Dosar Corespondență 1956, Episcopia Ortodoxă Română Cluj, Nr. 3962/1956.

7. Dosar Corespondenţă 1956, Of. Protopopesc Ort. Rom, Nr.484, Anul 1956, Luna VIII, ziua 7.

8. Dosar Corespondență 1957, Oficiul parohiei ort. rom. TELCIU, Nr.7-1957.

9. Dosar Corespondență 1958, Episcopia Ortodoxă Română Cluj, Nr. 5932/1958.

10. Dosar Corespondență 1958, Episcopia Ortodoxă Română Cluj, Nr. 4723/1958.

11. Dosar Corespondență 1958, Of. Parohial ort. rom. Poienile Zăgrii Suplai, Nr. 43/958.

12. Dosar Corespondenţă 1959, Of. Protopopesc Ort. Rom. raion Năsăud, Către Imputernictul Regional al Cultelor.

13. Dosar Corespondență 1961, Parohia Bis. Gersa 2, Nr.77, 23.XI.1961.

14. Dosar Corespondenţă 1961, Oficiul parohial ort. rom. Nepos, Nr. $121 / 1961$.

15. Dosar Corespondenţă 1961, Parohia ort. rom.Dumitra, R. Năsăud, Nr. 161/1961. 